\title{
Universiteit
}

Leiden

The Netherlands

\section{Resource constraints in a hydrogen economy based on renewable energy sources: an exploration}

Kleijn, R.; Voet, E. van der

\section{Citation}

Kleijn, R., \& Voet, E. van der. (2010). Resource constraints in a hydrogen economy based on renewable energy sources: an exploration. Renewable And Sustainable Energy Reviews, 14(9), 2784-2795. doi:10.1016/j.rser.2010.07.066

Version:

Publisher's Version

License:

Licensed under Article 25fa Copyright Act/Law (Amendment Taverne)

Downloaded from: https://hdl.handle.net/1887/3193712

Note: To cite this publication please use the final published version (if applicable). 


\title{
Resource constraints in a hydrogen economy based on renewable energy sources: An exploration
}

\author{
Rene Kleijn *, Ester van der Voet \\ Institute of Environmental Sciences (CML), Leiden University, P.O. Box 9518, 2300 RA, Leiden, The Netherlands
}

\section{A R T I C L E I N F O}

\section{Article history:}

Received 19 April 2010

Accepted 21 July 2010

\section{Keywords:}

Material constraints

Renewable energy

Hydrogen economy

Resources

PV

Wind

Transmission

Fuel cells

\begin{abstract}
A B S T R A C T
In order to tackle climate change, a transition to a renewable based energy system is crucial. A renewable based hydrogen economy is one of the possible implementations of such a system. The world receives ample energy from the sun that can be harvested by PV solar cells and, indirectly, by wind turbines. In order to use the most optimal locations for collecting and concentrating energy from these diffuse sources, a long distance transmission network is needed. Mature and semi-mature technologies are available for all parts of the system: from collection to transmission to end-use. In an early stage of development, when new technologies have to win market share from the existing energy system, their development is driven almost exclusively by the reduction of costs per $\mathrm{J}$ delivered. However, if a technology should be able to deliver tens to hundreds of EJ, resource constraints can become show stoppers. Many of the newest, most cost-efficient, energy technologies make use of scarce resources and, although they may play an important role in the transition process, they can not be scaled up the level we need for a complete transition. In most cases however other technologies are available that use more abundant materials, be it often at a cost of efficiency. The issue is not only with scarce resources. The sheer size of the energy transition will also challenge the industrial capacity for the mining and production of bulk materials like steel and copper.
\end{abstract}

(c) 2010 Elsevier Ltd. All rights reserved.

\section{Contents}

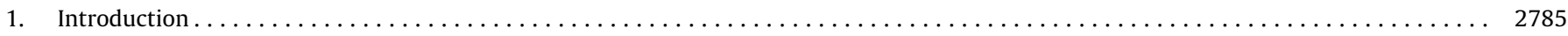

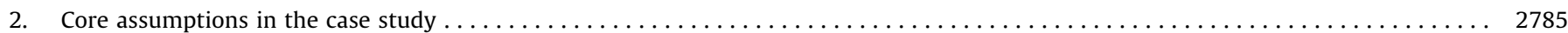

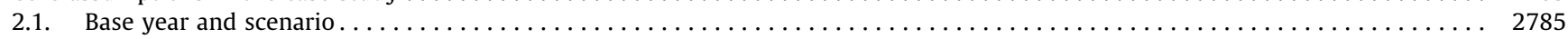

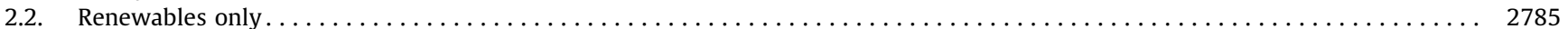

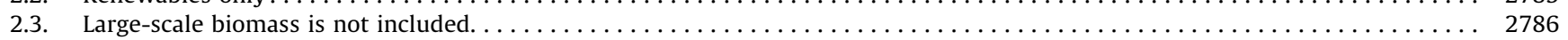

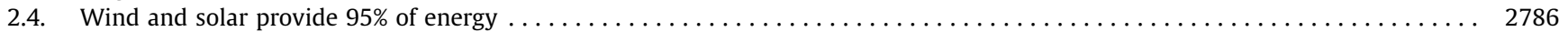

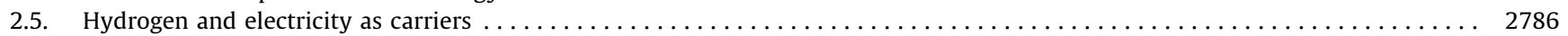

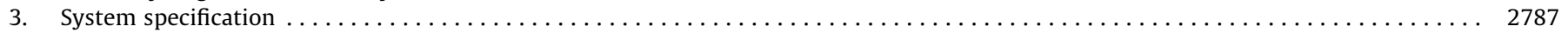

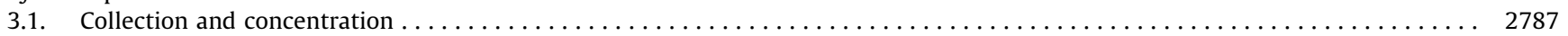

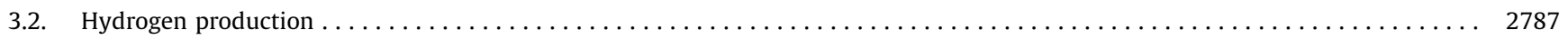

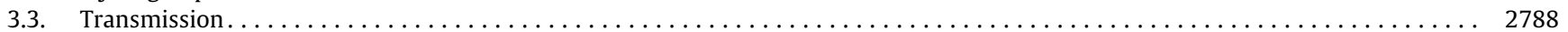

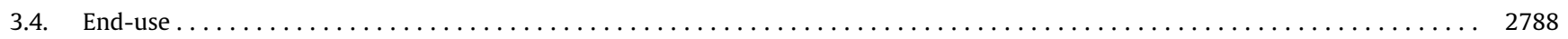

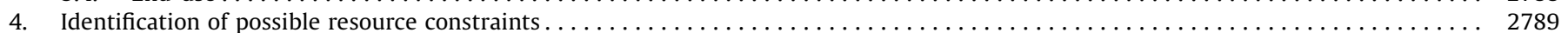

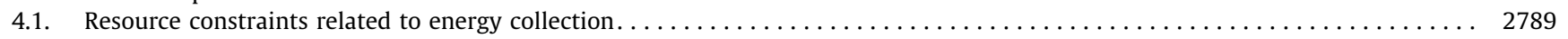

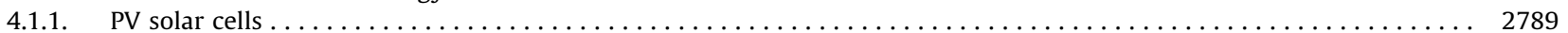

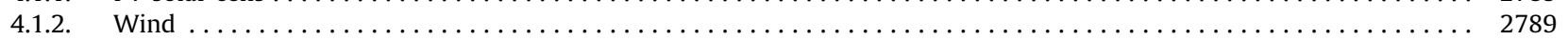

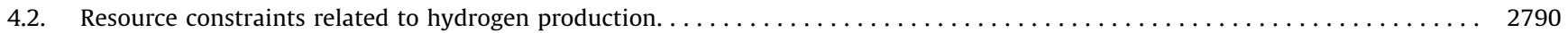

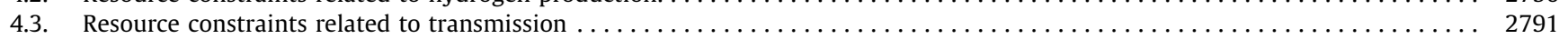

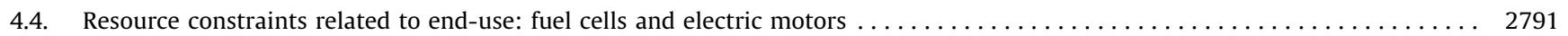

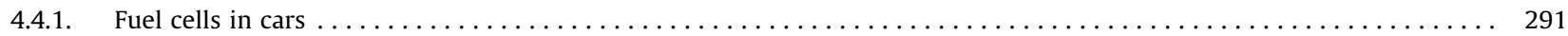

\footnotetext{
* Corresponding author. Tel.: +31 71 5271498; fax: +31 715277434 .

E-mail address: kleijn@cml.leidenuniv.nl (R. Kleijn).
} 


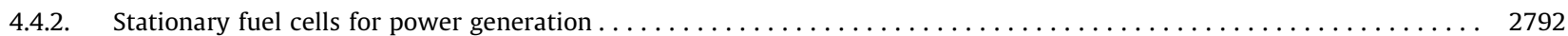

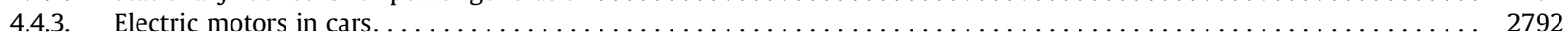

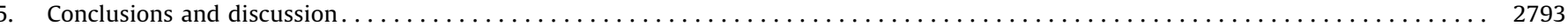

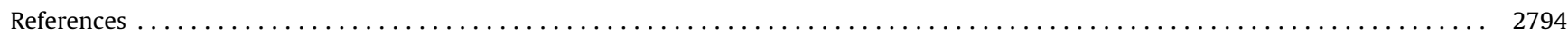

\section{Introduction}

The world is preparing for a transition from a fossil fuels based energy system to a system of renewable energy. One important option being discussed is the so-called hydrogen economy [1-4]: an energy system relying on hydrogen as its main energy carrier, instead of fossil fuels. This envisaged transition is partly driven by concerns about the environmental impact, especially global warming, connected to the current energy system, and partly by arguments related to security of energy supply.

Large-scale transitions cause many changes in society. It is a good idea, therefore, to assess beforehand what the consequences might be of such a transition. These consequences can be various. A first question is: does it actually solve the problem it is supposed to solve? Although a hydrogen economy is generally propagated as a "clean" alternative for the current fossil fuel based economy, it is the question how "clean" this hydrogen economy truly may be. Even if renewable energy sources would be used to produce hydrogen, a number of environmental issues would remain while additional new problems might occur. In a hydrogen economy, hydrogen and water are emitted. The emission of molecular hydrogen has been the topic of a debate on the possible effects of these emissions, specifically on stratospheric ozone and on climate change [5-7].

A second question relates to the feasibility of such a new system. Can it actually be built and implemented? When starting to envisage what a hydrogen economy would look like, a first step is to conceive a technological description of such a system. The production, transport and use of hydrogen as a fuel requires a whole series of new processes, materials, products and infrastructure which all will require resources and will have an environmental impact of their own. The same is true for the actual generation of energy, which in a renewable energy system will be done by other means than combusting fossil fuels, for example by using solar cells, wind power, biomass, etc. There is a high risk of running into resource constraints of one sort or another, simply because of the stunningly large scale of such a transition.

In this article, we will address this last issue, as a very important one. The central question in this paper is the following: Will a transition to a hydrogen economy based on renewable energy sources run into resource constraints?

In order to answer this question we try to create a picture of a world with hydrogen and electricity as the main energy carriers and renewables as the only energy source. We will, as well as possible, quantify the main parts of such a system, and we will assess whether or not resource constraints can be expected. Although it is clear to us that a world without fossil fuels is an extreme case [8] and there will be many hurdles on the way towards such a world, the dynamics of the transition process itself will not be addressed in this exploratory work. Also, we will not address economic and social consequences or the difficulties of actually realizing the transition politically or legally. It will be a technical description, targeted at the issue of potential "show stoppers" in a technical sense.

\section{Core assumptions in the case study}

For the technical specification of a renewables based hydrogen economy, we have defined the following starting points:
- the case describes a hypothetical energy system, roughly in the year 2050; the path towards this situation is not a part of the study;

- basic data like population, GDP and energy demand in 2050 are taken from the UNEP Markets First Scenario, see Table 1 [9];

- although in the Markets First Scenario the bulk of the primary energy still comes from fossil fuels, we describe a purely hypothetical situation in which all energy comes from renewable sources;

- we assume that the role of biomass based energy will be limited;

- we assume that the renewables mix for primary energy will be 80\% PV solar, 15\% wind and 5\% other (renewable) sources;

- electricity and hydrogen are considered the only two energy carriers.

These starting points are elaborated below.

\subsection{Base year and scenario}

The choice for the year 2050 is rather arbitrary as a year which is sufficiently far in the future to envisage a novel energy system while not too distant to still have reasonable estimates of basic data like world population and GDP. Furthermore, if we seriously want to address climate change the energy system needs to change dramatically within this time frame. The Markets First Scenario was chosen because (1) it is most in line with current world economic and demographic developments and (2) it results in a relatively high future energy demand which makes it a worst case. The Markets First Scenario envisages a world in which marketdriven developments converge on the values and expectations that prevail in industrialized countries [9]. World integration, globalization, free trade and reliance on market-based approaches are the main directions for development. GDP/capita and energy consumption/capita both grow rapidly in this scenario between now and 2050.

\subsection{Renewables only}

In the Markets First Scenario, the total primary energy production in 2050 will be about $1300 \mathrm{EJ}$, more than 2.5 times the primary energy use in 2005 (about 514 EJ) (see Table 1). In almost all current projections of future energy use fossil fuels will still be the dominant source of energy in the coming decades $[10,11]$. However, in our extreme case study we assume that all energy is generated from renewable sources. In the Markets First Scenario, where globalization and free trade rule, the primary energy mix will be dependent on local availability and world market prices. If one looks at the potential availability of the different renewable sources (Table 2) it is clear that the bulk of the primary energy in the Markets First Scenario will have to come from wind and solar power.

Table 1

Key variables of the IPCC SRES Markets First Scenario.

\begin{tabular}{lrrll}
\hline & \multicolumn{1}{c}{1990} & \multicolumn{1}{c}{2050} & Unit & Multiplier \\
\hline Population & 5302 & 9386 & Million & 1.8 \\
GDP & 25,293 & 191,767 & Billion & 7.6 \\
Primary energy use & 356 & 1278 & EJ \$ (1995) & 3.6 \\
\hline
\end{tabular}

Source: [9]. 
Table 2

Availability of renewable energy (excluding biomass and extraterrestrial collection).

\begin{tabular}{|c|c|c|c|c|c|}
\hline & W & $\mathrm{J} / \mathrm{a}$ & $\begin{array}{l}\text { Multiplier for } \\
1990 \text { energy } \\
\text { use }\left(3.56 \times 10^{20} \mathrm{~J}\right)\end{array}$ & $\begin{array}{l}\text { Multiplier for } \\
2050 \text { energy } \\
\text { use in MF } \\
\text { scenario }\left(1.28 \times 10^{21} \mathrm{~J}\right)\end{array}$ & Source \\
\hline \multicolumn{6}{|l|}{ Solar } \\
\hline Solar energy reaching earth surface & $2.6 \times 10^{16}$ & $8.2 \times 10^{23}$ & 2303 & 642 & [12] \\
\hline $\begin{array}{l}\text { Collectable in Sahara desert with current } \\
\text { PV efficiency }(10 \%)\end{array}$ & $2.1 \times 10^{14}$ & $6.5 \times 10^{21}$ & 18 & 5 & Calculated \\
\hline \multicolumn{6}{|l|}{ Wind } \\
\hline Total kinetic energy in the earth atmosphere & $3.5 \times 10^{15}$ & $1.1 \times 10^{23}$ & 310 & 86 & [13] \\
\hline Total in bottom 100 meter & $1.3 \times 10^{15}$ & $4.0 \times 10^{22}$ & 113 & 31 & [13] \\
\hline Maximum practically realizable & $5.7 \times 10^{12}$ & $1.8 \times 10^{20}$ & 0.51 & 0.14 & {$[14]$} \\
\hline Technical potential & $1.5 \times 10^{13}$ & $4.8 \times 10^{20}$ & 1.3 & 0.37 & {$[15]$} \\
\hline \multicolumn{6}{|l|}{ Hydro } \\
\hline On basis of precipitation on land & $1.0 \times 10^{13}$ & $3.0 \times 10^{20}$ & 0.8 & 0.2 & [12] \\
\hline Principally available & $1.2 \times 10^{12}$ & $3.8 \times 10^{19}$ & 0.11 & 0.030 & {$[12]$} \\
\hline Realistic reserve hydro & $6.3 \times 10^{11}$ & $2.0 \times 10^{19}$ & 0.055 & 0.015 & {$[12]$} \\
\hline \multicolumn{6}{|l|}{ Tidal } \\
\hline Total tidal energy & $3.0 \times 10^{12}$ & $9.5 \times 10^{19}$ & 0.27 & 0.074 & [12] \\
\hline Tidal world potential at best sites & $1.2 \times 10^{11}$ & $3.8 \times 10^{18}$ & 0.011 & 0.0030 & {$[12]$} \\
\hline \multicolumn{6}{|l|}{ Wave } \\
\hline Total wave energy & $1.1 \times 10^{11}$ & $3.6 \times 10^{18}$ & 0.010 & 0.0028 & {$[12]$} \\
\hline \multicolumn{6}{|l|}{ Geothermal } \\
\hline Total stored in the Earth & & $4.00 \times 10^{30}$ & $1.1 \times 10^{10}$ & $3.1 \times 10^{9}$ & [12] \\
\hline Total heat outflow & $3.00 \times 10^{13}$ & $9.46 \times 10^{20}$ & 2.7 & 0.7 & [12] \\
\hline
\end{tabular}

\subsection{Large-scale biomass is not included}

Next to wind and solar sources, biomass is the only source that could, in theory, provide a substantial contribution to the world's energy supply in 2050. The estimates of the potential contribution of biomass to the total world energy supply vary from 0 to over $1000 \mathrm{EJ} / \mathrm{a}$ of which over $90 \%$ would have to come from high quality agricultural land [16]. A detailed and regionalized study [15], concludes that the contribution of biomass to the fuel production in 2050 could reach a level equal to the present oil demand (180 EJ/ a). The largest part of the biomass would have to come from the former USSR, East Asia, Africa and South America, assuming a large increase in agricultural productivity in these areas. Others (e.g. [17]) dispute this and state that the required increase in biomass production of an order of magnitude is impossible in view of land and water constraints. By-and-by it is becoming clear that biomass can provide only a limited amount of the world's energy. We consider competition with nature and food production for the limited land area that can be used for the production of biomass, ${ }^{1}$ such a problem that we exclude biomass as a significant source of renewable energy. This in contrast to solar energy which can be collected in areas where biodiversity is minimal and agriculture is not possible, and to wind turbines which can either be used off shore or combined with agriculture. Moreover, biomass production dedicated for energy purposes is less efficient from an energy perspective than PV solar cells. ${ }^{2}$ The use of waste biomass and residues as a source of energy is less problematic. However, the contribution to the total primary energy production will probably be relatively small: 30-108 EJ/a [15].

\footnotetext{
${ }^{1}$ The production algae and kelp does not require arable land but is related to problems of its own. For example in order to have substantial production levels of kelp nutrient rich water would have to be pumped towards the kelp fields which would require energy and lower the overall efficiency dramatically [69].

2 The energy need for the production of Rape Methyl Ester is for example $16 \mathrm{GJ} \mathrm{ha}^{-1} \mathrm{a}^{-1}$ while it delivers an equivalent of $43 \mathrm{GJ}$ of fossil energy [70]. With poplar clones a net energy collection of $260 \mathrm{GJ} \mathrm{ha}^{-1} \mathrm{a}^{-1}$ has been reported [71]. This is equivalent to an efficiency of respectively $0.08 \%$ and $0.8 \%$ (biomass out (HHV)/ solar in) while current PV systems have an efficiency between 6 and 15\%) [39].
}

\subsection{Wind and solar provide $95 \%$ of energy}

Wind may provide about $180 \mathrm{EJ} / \mathrm{a}$ [14] or about $15 \%$ of the 2050 total energy demand, hydropower up to $3 \%$ [12]. All other renewable energy sources will be used in addition in places where they are readily available but will probably not provide more than $1 \%$ of the world's total primary energy use. ${ }^{3}$ In order to simplify the analysis at hand we will focus on the $95 \%$ that can be provided via wind power (15\%) and solar radiation (80\%) leaving out all other sources.

\subsection{Hydrogen and electricity as carriers}

We will focus on two main carriers for the future energy system: electricity and hydrogen. Current renewable energy sources (except biomass) directly produce electricity. Since any energy conversion is associated with a loss of exergy, conversions are limited as much as possible in an optimal energy system. Electricity is an excellent energy carrier for stationary applications but it is difficult to store in large quantities. This is problematic in a renewable based energy system because the availability of renewable sources is highly variable through weather conditions, seasonal changes and day and night rhythms. It also implies that electricity is not very useful in mobile applications that require more than a few Watt, like transportation. Only recently battery technology has improved in such a way that the first full electric vehicles are being brought to consumer markets. It is not clear which technology, hydrogen fuel cells or full electric cars will be dominant. Hydrogen is still seen by many as the preferable energy

\footnotetext{
${ }^{3}$ At the moment the way in which society uses energy is quite wasteful. High exergy energy sources like fossil fuels are often used in applications that actually only require low-exergy energy. An example is heating of buildings. Although some heating is done by using waste heat from industry, low temperature geotherma sources and passive solar energy, the contribution of these sources is still very limited, mainly because the use of high-exergy energy is relatively cheap and requires little investments because existing infrastructure can be used. Based on the current trends and the Markets First scenario, we explore the scenario in which lowexergy energy sources will remain of marginal importance.
} 
carrier for the use in mobile applications. In our scenario for 2050 we assume hydrogen will be used as the energy carrier in high power mobile applications (mainly in transport).

\section{System specification}

The key figures from the Markets First Scenario are combined with data from literature on the availability of renewable energy sources and data on relevant energy technologies. We have used this information to generate a rough but more or less complete and quantitative overview of what a world based on renewable energy sources and hydrogen as an energy carrier could look like in 2050. The entire energy "life-cycle" will be taken into account: from the energy collection, via the transmission and distribution of this energy, to the utilization of this energy by the end-users. The infrastructure of the renewable based hydrogen economy is described and the material flows connected to this infrastructure are quantified over the next sections. On the basis of this quantified system description, the bottlenecks with regard to resource availability will be identified.

A general overview of our hydrogen energy system based on renewable energy sources is given in Figs. 1 and 2. Renewable energy is collected and concentrated, preferably in locations where conditions are optimal for a given source, transmitted to the centers of economic activity and distributed to the end-users. Both electricity (Fig. 1) and hydrogen (Fig. 2) can be used as a carrier for long range transmission.

\subsection{Collection and concentration}

In order to collect substantial amounts of useful energy from wind and solar radiation, large surface areas are needed, preferably in places with optimal conditions for collection. These optimal locations are often not the same as the locations where the energy is used. For example, the best places to collect solar energy, deserts, are often located far from the economic and industrial centers of

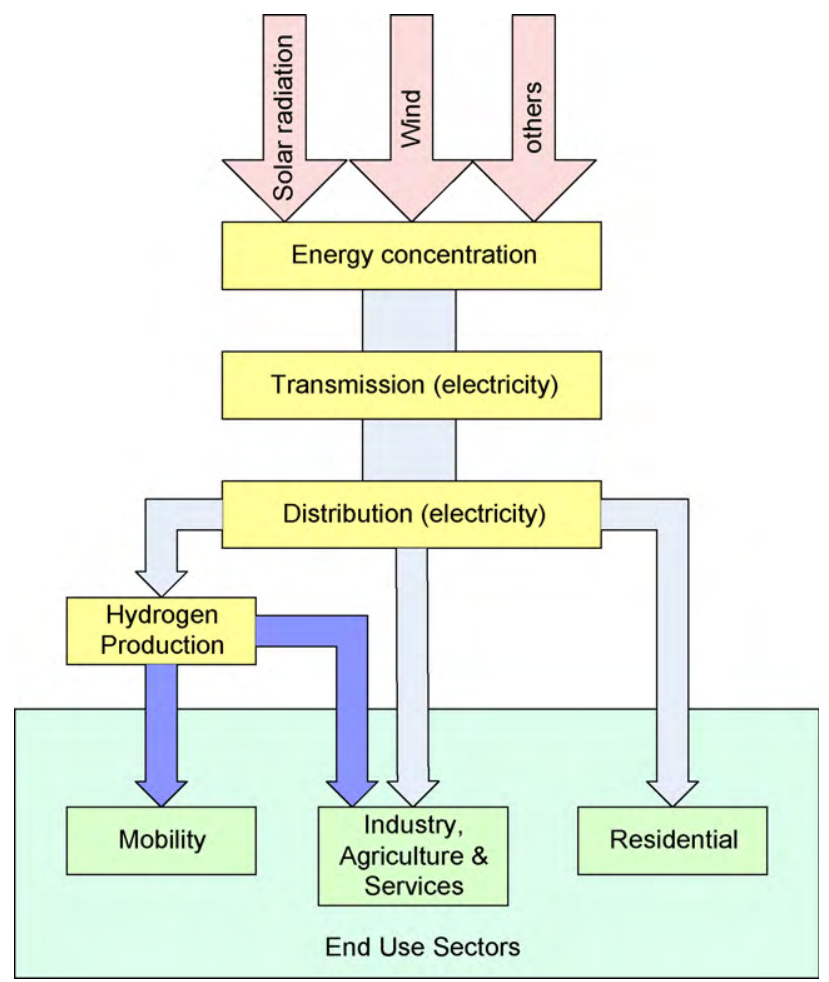

Fig. 1. Main structure of a renewable based hydrogen energy system with electricity as the carrier in transmission.

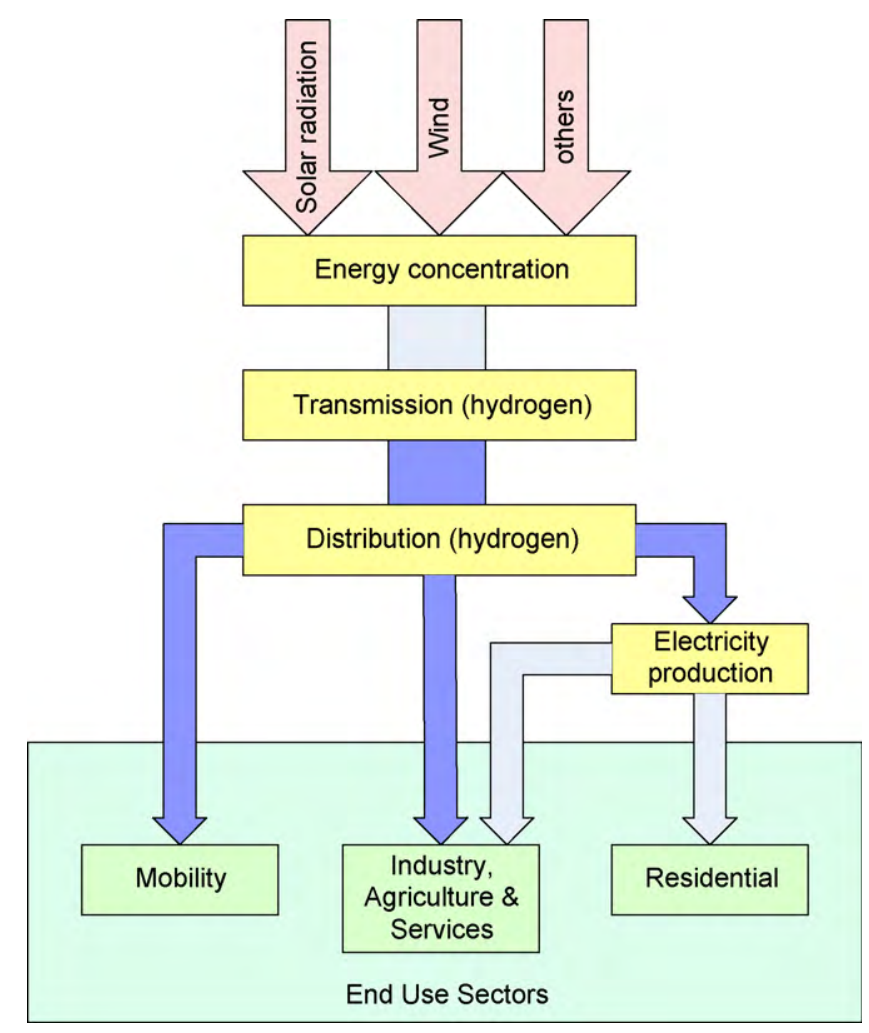

Fig. 2. Main structure of a renewable based hydrogen energy system with hydrogen as the carrier in transmission.

the world (e.g. [18,19]). Therefore, an extensive long distance transmission infrastructure is needed to get the energy to the endusers. Next to that, solar and wind energy are intermittent by nature, which increases the importance of a long distance transmission network in order to buffer the system for temporal local shortages (e.g. [20]).

\subsection{Hydrogen production}

Hydrogen can be produced via two routes:

1. via electricity in a two step process: solar and wind energy are used to produce electricity, which in a next step is used for the electrolysis of water to form hydrogen.

2. directly from water and solar energy via photolysis.

The second route has two main advantages: an energy transformation step would be eliminated, thereby increasing the efficiency of energy system as a whole, and two expensive and complex pieces of equipment, PV cells and electrolysis cells, would be replaced by one piece of equipment, the photolysis cell. However, the technology still suffers from severe practical problems and needs to be developed further. ${ }^{4}$

Next to this photochemical photolysis, a biological route exists. Algae or bacteria or their enzymes (hydrogenases) are used in light-driven bioreactors to split water [21]. However, this route is also still in the phase of early laboratory scale experiments.

\footnotetext{
${ }^{4}$ This technique was first demonstrated by [72]. Problems like the lack of efficient light absorption and the corrosion of the semiconductor have been identified by [73]. In order to avoid these problems, tandem cells are now being developed in which a photo-electrolysis cell is put in series with a solar cell which allows the use of semiconductors that are more stable in water like tungsten oxide. However, the published efficiencies of these tandem cells are at the moment as low as $4.5 \%$ [74].
} 
Table 3

A comparison of transmission losses between AC, HVDC and $\mathrm{H}_{2}$ pipelines.

\begin{tabular}{llll}
\hline & Overhead AC & HVDC & $\mathrm{H}_{2}$ pipeline \\
\hline Energy losses per 100 km (\%) & 1 & 0.4 & 0.8 \\
AC/DC conversion losses & 0 & $1-2 \%$ & $\mathrm{NA}$ \\
\% Losses for $1500 \mathrm{~km}$ & 15 & 8 & 12 \\
\% Losses for $3000 \mathrm{~km}$ & 30 & 14 & 24 \\
Source & {$[12]$} & {$[23]$} & {$[24]$} \\
\hline
\end{tabular}

Because both the direct photolytic route and the biological route are still in the early stages of development, it is hard to say anything about their practical potential or link them to an estimate of resource requirements. We will therefore focus on PV coupled to electrolysis for hydrogen production.

Electrolysis of water can be done with different processes:

- alkaline electrolyzers (commercial large-scale units);

- polymer electrolyte membrane (PEM) electrolyzers (protypes and commercial units);

- solid oxide electrolyzers (lab-stage and commercial units).

All three of these options will be analyzed although the main focus will be on alkaline electrolyzers.

\subsection{Transmission}

Both hydrogen and electricity can be used for long range transmission of energy, and both options will explored in this study. The technology to transport electricity over long distances via a high voltage AC power grid is already operational today. Transmission losses depend on the transport distances. In the1990s the UK the average losses, excluding transformation and distribution, were $1.5-2 \%$ [22]. In Table 3 an overview is given of the losses in different types of transmission: overhead AC, HVDC and hydrogen pipelines. High voltage DC (HVDC) lines are today used to transport about $2 \%$ of all electricity in around 90 projects all over the world [23]. Trans-ocean HVDC cables that have been used to transport electricity from Scandinavia to other parts of Europe have losses of under $0.4 \%$ per $100 \mathrm{~km}$. However, a $1-2 \%$ loss should be added for the AC/DC/AC conversion $[23,25]$ so, from an energy efficiency perspective, this technique is only preferred for distances over $300 \mathrm{~km}$. From a viewpoint of investment costs, DC transmission becomes favorable over AC lines over $50 \mathrm{~km} .{ }^{5}$ In our case study we therefore assume HVDC for long distance transmission. HVDC cables are either bipolar or monopolar. A bipolar cable has a better performance [26] and will therefore be assumed in our case study. Conductors in HVDC lines are traditionally made from copper although aluminum conductors are nowadays sometimes used in light weight, low capacity cables that are applied for shorter distances.

Hydrogen can be transported as a gas via pipelines or as a liquid in cryogenic dewar vessels on ships, trucks or trains. Since hydrogen is widely used in oil refining and chemical industry, a commercial system of hydrogen distribution is already in place (e.g. [27]). When hydrogen is transported via pipelines specifically designed for hydrogen transport, losses can be very low. Overall losses from the pipelines in Germany are about $0.1 \%$ per year [27]. The pumping of a gas through a pipeline requires energy. In natural gas pipelines about $0.2 \%$ of the transported amount of gas is used for compressors, every $100 \mathrm{~km}$ at a rate of $10 \mathrm{~m} / \mathrm{s}$ [28]. Because hydrogen contains roughly a factor three less energy per unit of volume than natural gas, more energy is needed for compression when transporting hydrogen through pipelines: about $0.8 \%$ every $100 \mathrm{~km}[28,23]$. In Table 3 transmission via electricity is compared with hydrogen pipelines. For a transmission distance of $1500 \mathrm{~km}$ losses from $\mathrm{H}_{2}$ pipelines are 1.5 times as high as those from HVDC cables. If the distances increase the relative difference increases as well. However, by optimizing the hydrogen pipelines (larger diameter, improved gas turbines for compression, etc.) losses could be reduced to less than $10 \%$ for $3000 \mathrm{~km}[24,29]$.

Because hydrogen molecules are very small, hydrogen can easily diffuse through most materials and seals and it can cause severe degradation of steels. Therefore, pipelines used for transporting hydrogen must be made of high quality nonporous materials such as stainless steel [29]. Hydrogen can be added to steel natural gas pipelines in mixtures up to $30 \mathrm{vol} \%$ (10\% in energy terms) $[29,30]$. A problem for transport through steel pipes is the so-called hydrogen embrittlement. This phenomenon is not completely understood, but it refers to cracks and blisters in the metal due to hydrogen permeation in the steel, which result in leakages. To avoid embrittlement, pipes can be coated, small quantities of $\mathrm{CO}, \mathrm{SO}_{2}$ or $\mathrm{O}_{2}$ can be added [29,31] or embrittlement-resistant steels can be used. Transport of hydrogen through plastic pipes is also problematic because hydrogen permeates through plastic four to six times as fast as natural gas [29,31].

Liquefaction of hydrogen can be applied by cooling hydrogen to extremely low temperatures (below $-253^{\circ} \mathrm{C}$ ). The energy content of $1 \mathrm{~L}$ of liquefied hydrogen is much higher than the energy content of a liter of compressed gaseous hydrogen. The main disadvantages are that the energy costs are high and that the losses during handling and transport are relatively high too. One of the reasons for these losses is that boil-off, evaporation of hydrogen due to temperature changes, is inevitable. However, the hydrogen that escapes in this way can, in some cases, be captured again and used for the propulsion of the vehicle in which the transport takes place. Although the transport of liquid hydrogen is technically feasible, the costs, both in terms of energy as in terms of money, will be so high that it will probably only be used under very specific circumstances and it will not compete with pipeline transport. Pipelines are the preferred transport option for large quantities and long distances while liquid hydrogen is preferred for smaller volumes over long distances [29]. Therefore, in our case we assume pipelines for long distance bulk transport of hydrogen.

\subsection{End-use}

Although electricity and hydrogen are interchangeable as energy carriers in distribution, this is not the case in end-use. As transport fuel, hydrogen can either be combusted like gasoline and kerosene, or used in fuel cells. Fuel cells convert hydrogen into electricity, which is used to power the electric motors that are used to make the wheels turn and propel the vehicles. Even fuel-cell cars that are filled up with hydrogen will thus ultimately be powered by electricity. In cars, the dominant hydrogen based technology is fuel-cell cars. Prototypes of internal combustion engine (ICE) based hydrogen cars exist (e.g. BMW), but this should be seen purely as an intermediate technology that will help the transition to a hydrogen fuel-cell vehicles [32]. In aviation, the dominating propulsion technology is jet engines. Since these make direct use of the exhaust gases to propel the plane, combustion of hydrogen would be the preferred option here (e.g. [33]). Consumer electronics that need a lot of power, like refrigerators, washing

\footnotetext{
${ }^{5}$ Other advantages of DC lines are [75]: (1) it is possible to link two asynchronous power grids (i.e. the frequency at either end can differ); (2) DC lines, unlike AC lines, do not have the drawback of so-called reactive current which can substantially reduce the power throughput. This problem does not occur in overhead lines; (3) the direction and the magnitude of the power flow can be controlled; and (4) a given cable can carry more power in DC than in AC.
} 
machines, TV's and stereos, will remain grid connected and powered by electricity. Smaller electronics like laptops and mobile phones will either be battery powered or powered by small fuel cells, that in turn produce the electricity that powers these devices.

\section{Identification of possible resource constraints}

To identify possible resource constraints of the hydrogen economy, a quantification will be attempted with regard to the most important elements of the system described above:

- energy collection via PV cells and wind turbines;

- hydrogen production via electrolysis;

- long range electricity and hydrogen transmission;

- end-use: fuel cells \& electric motors.

\subsection{Resource constraints related to energy collection}

\subsubsection{PV solar cells}

If $80 \%$ of the primary energy in 2050 comes from solar, this means that around 1000 EJ will be produced via solar energy. Part of this could come from built-up area. The IEA [34] concludes that in selected developed countries between $30 \%$ and $120 \%$ of the electricity use in that year could come rooftops. Here we assume a theoretical maximum of about $15 \%$ of primary energy in 2050 (around $200 \mathrm{EJ}$ ) that could come from built-up area. ${ }^{6}$ Even with this maximized amount of PV from built-up are this would mean that $65 \%$ of the primary energy would have to come from other surfaces. This implies that land will be used that is currently used for agriculture, or that is currently not used by humans. In (sub)tropical desert areas on average about $7.2 \mathrm{GJ} / \mathrm{m}^{2}$ reaches the earth surface every year [13]. Assuming a 10\% efficiency, an area of 1.0 million $\mathrm{km}^{2}$ would be needed to produce $845 \mathrm{EJ} / \mathrm{a}$ (65\% of $1300 \mathrm{EJ} / \mathrm{a}$, see earlier). This area is equivalent to about $10 \%$ of the Sahara desert area, divided over the different continents. At a latitude of $50^{\circ}$ (Vancouver, Paris) the average annual incoming solar energy on ground level is around $3.6 \mathrm{GJ} / \mathrm{m}^{2}[13]$. Based on this irradiation an area of 2.0 million $\mathrm{km}^{2}$ would be needed to supply the remaining $65 \%$ of the total energy use, equivalent to about four times area of France. If, for example, OECD Europe would want to be self-sufficient in energy terms, it should be able to collect $100 \mathrm{EJ} / \mathrm{a}$ in 2050 [35]. In order to achieve this, $4 \%$ of the total land area (or $10 \%$ of the agricultural area) would have to be re-allocated to collect solar energy, in addition to a 15\% use of wind energy and a $15 \%$ use of solar cells on built-up land, and the assumed $5 \%$ other renewable sources.

At the moment, different solar cells are available. There are different types of silicon cells: monocrystalline, polycrystalline and amorphous. All three forms of silicon are produced from sand of which supply is abundant. The only other materials in the cells themselves are dopants, mostly phosphorus and boron. For both materials the application in electronics is only a very small fraction of the total production so no constraints are in sight [36]. Amorphous Si cells are cheap but have low efficiency, while crystalline Si cells have high efficiencies but they are also expensive and energy intensive to produce [37]. Therefore new thin-film PV cells have been developed that can be produced at lower costs [37,38]. At the moment the main thin-film technologies are cadmium telluride (CdTe) and copper indium gallium diselenide (CIGS) [38]. Typical efficiencies of different cells are given in Table 4 . Since these thin-film cells use a

\footnotetext{
${ }^{6}$ This assumption is based on data on built-up area in different countries (WRI online database land use), the assumption that $20 \%$ of this area would be suited for PV collection, an average incoming solar radiation of about $110 \mathrm{~W} / \mathrm{m}^{2}$ and a PV efficiency of $10 \%$.
}

Table 4

Efficiency of PV cells.

\begin{tabular}{lll}
\hline & $\begin{array}{l}\text { Record cell } \\
\text { efficiency (\%) }\end{array}$ & $\begin{array}{l}\text { Record module } \\
\text { efficiency (\%) }\end{array}$ \\
\hline Si (Crystalline) & 24.7 & 22.7 \\
Si (MultiCrystalline) & 20.3 & 15.3 \\
Si (thin film) & 16.6 & 8.2 \\
Si (amorphous) & 9.5 & N/A \\
CIGS (cell) & 18.4 & 13.4 \\
CdTe & 16.5 & 10.7 \\
Concentrator Si & 26.8 & N/A \\
$\quad$ (parabolic disc) & & \\
Concentrator GaInP/GaAs/ & 34.7 & N/A \\
$\quad$ Ge (2-terminal) & & \\
\hline
\end{tabular}

Source: [39].

combination of less common materials, the supply of these materials can be an issue of concern once production reaches a substantial level.

During the last decade several studies have addressed the issue of material constraints of thin-film PV [37-42]. The material needs of the four main non-silicon solar cells have been calculated by [42]. On the basis of these numbers and our scenario we calculated resources constraints for these technologies which are presented in Table 5. It is apparent that current reserves would not allow a substantial contribution of these cells to the solar energy collection we need in our scenario for 2050. All four technologies will be limited to a maximum of less than $1 \%$ (10 EJ/a) of the total required energy collection. In more recent and more detailed work $[37,38]$ the limits for current thin-film technologies (CdTe and CIGS) are estimated at around 10-100 EJ/a [37,38]. However there are large differences in the material constraints for different technologies. Some, more unconventional, thin-film PV technologies (especially $\mathrm{FeS}_{2}$ ) look very promising from the perspectives of material constraints and can be scaled up to the level of over thousand EJ/a [37]. Considering these material constraints ${ }^{7}$ it seems that the use of current thin-film cells based on rare materials will be limited. In a world based largely based on solar energy, the bulk of the solar cells would thus have to be based on new thin-film materials or amorphous silicon. Next to the PV cells themselves the production of PV modules requires additional materials, these are not quantified in this study.

\subsubsection{Wind}

As stated before wind may provide about $180 \mathrm{EJ}$ or about $15 \%$ of the 2050 total energy demand. This would mean that about $195 \mathrm{EJ} /$ a will be produced via wind turbines. In January 2008, 94 GWe of wind power was installed, delivering about $1.4 \%$ of global electricity demand [23]. Thus in order to produce 190 EJ in 2050 the installed capacity has to increase by a factor of $250,{ }^{8}$ resulting in a capacity of 24 TWe. Present turbines have a capacity of around 1-2 MWe on land and up to 3-5 MWe for offshore sites [12]. However, the size of wind turbines has been growing rapidly: from $0.5 \mathrm{MW}$ in 1992 to $4.5 \mathrm{MW}$ in 2002 [43]. If we assume an average capacity of 2 MWe, 12 million of these large turbines would have to be installed.

\footnotetext{
${ }^{7}$ Another issue with technologies using rare materials is, that the energy payback time as well as environmental impacts are relatively high because of the energy-intensive mining and refining processes. It was calculated, based on current technologies, that the full life cycle energy payback time is 6.3 years for an indium gallium phosphide (InGaP) module and only 3.5 years for a mono-crystalline $\mathrm{Si}$ module [76]. They also estimated that the environmental impact of the InGaP module was $80 \%$ higher than the impact of a mono-crystalline Si module. This reinforces the conclusion that these types of solar cells cannot contribute more than a small fraction to worldwide energy generation.

8 This may seem like a very high number but at an annual growth rate of $14 \%$ would be enough to achieve this in 2050. The last ten years, 1999-2008, the annual growth rate in installed wind capacity has been around 25\% [23].
} 
Table 5

Material constraints of different elements for four thin-film solar cell technologies.

\begin{tabular}{|c|c|c|c|c|c|c|}
\hline Cell type & Element & $\begin{array}{l}\text { Requirement } \\
\left(\mathrm{g} / \mathrm{m}^{2}\right)\end{array}$ & $\begin{array}{l}\text { Reserves } \\
1998(\mathrm{Gg})\end{array}$ & $\begin{array}{l}\text { Refinery } \\
\text { production } \\
1997(\mathrm{Gg} / \mathrm{a})\end{array}$ & $\begin{array}{l}\text { Crystal } \\
\text { abundance } \\
\text { (ppm) }\end{array}$ & $\begin{array}{l}\text { Needed for } \\
1.7 \times 10^{6} \mathrm{~km}^{2}(\mathrm{Gg})\end{array}$ \\
\hline \multirow[t]{2}{*}{ CdTe } & $\mathrm{Cd}$ & 6.3 & 600 & 20 & 0.1 & 10,000 \\
\hline & $\mathrm{Te}$ & 6.5 & 20 & 0.29 & 0.005 & 11,000 \\
\hline \multirow[t]{3}{*}{ CIGS } & $\mathrm{Se}$ & 4.8 & 70 & 2.2 & 0.12 & 7900 \\
\hline & $\mathrm{Ga}$ & 0.53 & 110 & 0.054 & 15 & 880 \\
\hline & In & 2.9 & 2.6 & 0.2 & 0.05 & 4800 \\
\hline aSiGe & $\mathrm{Ge}$ & 0.44 & 2 & 0.063 & 1.4 & 730 \\
\hline Dye-sensitised & $\mathrm{Ru}$ & 0.1 & 6 & 0.011 & 0.0001 & 170 \\
\hline
\end{tabular}

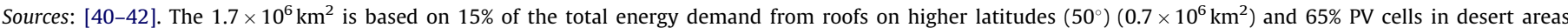
$\left(1.0 \times 10^{6} \mathrm{~km}^{2}\right)$.

Table 6

Material use wind turbines.

\begin{tabular}{|c|c|c|c|c|c|c|c|c|}
\hline & \multirow{2}{*}{$\begin{array}{l}2 \mathrm{MW} \\
\text { offshore } \\
\text { ton/MWe }\end{array}$} & \multirow{2}{*}{$\begin{array}{l}800 \mathrm{~kW} \\
\text { onshore } \\
\text { ton/MWe }\end{array}$} & \multirow{2}{*}{$\begin{array}{l}2 \mathrm{MW} \\
\text { offshore } \\
\text { Mton/24 TWe }\end{array}$} & \multirow{2}{*}{$\begin{array}{l}800 \mathrm{~kW} \\
\text { onshore } \\
\text { Mton/24 TWe }\end{array}$} & \multirow{2}{*}{$\begin{array}{l}\text { \% Reserve base } \\
24 \text { TWe with } \\
2 \mathrm{MW} \text { off shore }\end{array}$} & \multirow{2}{*}{$\begin{array}{l}\text { \% Reserve base } \\
24 \text { TWe with } \\
800 \mathrm{~kW} \text { onshore }\end{array}$} & \multicolumn{2}{|c|}{$\begin{array}{l}\text { Multiplier of world annual (mine) } \\
\text { production } 2008\end{array}$} \\
\hline & & & & & & & $2 \mathrm{MW}$ offshore & $800 \mathrm{~kW}$ onshore \\
\hline Steel & 148 & 135 & 3551 & 3244 & 2.2 & 2.0 & 3.0 & 2.7 \\
\hline Aluminum & 0.42 & 0.26 & 10 & 6 & & & & \\
\hline Copper & 2.75 & 1.83 & 66 & 44 & 6.6 & 4.4 & 4.2 & 2.8 \\
\hline Lead & 3.79 & 0 & 91 & 0 & & & & \\
\hline Plastics & 2.09 & 1.92 & 50 & 46 & & & & \\
\hline Concrete & 1050 & 306 & 25,100 & 7340 & & & 1.3 & 0.38 \\
\hline Gravel & 150 & 0 & 3600 & 0 & & & & \\
\hline Neodymium & 0.15 & & 3.6 & & & & 180 & \\
\hline
\end{tabular}

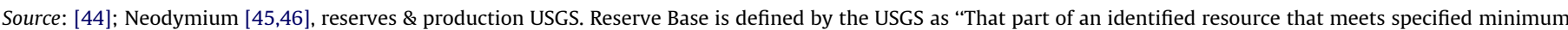

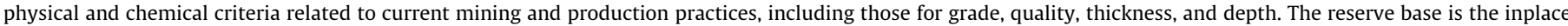
demonstrated (measured plus indicated) resource from which reserves are estimated." [47].

An indication of the material use in wind turbines is given in Table 6. The amount of copper needed for these turbines is between 2 tons/MWe (onshore) and 3 tons/MWe (offshore) per turbine. This means that for the total 24 TWe, more than 50 million ton copper is needed. This is equivalent to about $7 \%$ of current reserve base ${ }^{9}$ and more than 4 times the worldwide mine production in 2008. The use of iron and steel is around 140 ton/MWe and thus more than 3 billion ton for the total 24 TWe. This is equivalent to around $2 \%$ of the base reserve of iron ore and, in terms of iron content of the ore, about 3 times the current iron ore production.

Next to the base metals which are used in wind turbines more exotic materials are sometimes used as well. Neodymium is a rare earth metal which is used in permanent magnets. Neodymium magnets are preferred above other permanent magnets because they can provide the same magnetic strength with smaller and lighter magnets. Using permanent $\mathrm{Nd}$ magnets in wind turbines can slightly increase their efficiency, reduce maintenance costs and reduce the weight of the generator, all because they can make gearboxes redundant $[45,46]$. In state of the art wind turbines with direct-drive permanent-magnet generators about $550 \mathrm{~kg}$ permanent magnets or $150 \mathrm{~kg}$ of neodymium is used per MWe $[45,46]$. This would mean that around 3.6 million ton Nd would be needed for the total 24 TWe in our scenario. This is about 180 times the current annual mine production. At the moment very few wind turbines actually use direct-drive with permanent magnets and most use electromagnets in geared generators which are made of copper and iron. Neodymium constraints will therefore not be a show stopper for large-scale application of wind turbines in general but it will limit the market share of certain new types of

\footnotetext{
${ }^{9}$ As defined by the USGS: base reserve: "That part of an identified resource that meets specified minimum physical and chemical criteria related to current mining and production practices, including those for grade, quality, thickness, and depth."
}

wind turbines. Even more so because the turbine producers would have to compete with car manufacturers (see under Section 4.4) and with other renewable energy sources in which permanent magnets are used [46].

The amount of concrete needed to build a wind turbine is between 300 ton/MWe (onshore) and 1000 ton/MWe (offshore) which means that for 24 TWe between 7 and 25 billion ton of concrete needs to be produced. If the average cement content of concrete is set at $15 \%$ the amount of cement needed to produce this concrete is between $40 \%$ and $130 \%$ of the annual world cement production in 2008 [47]. For cement, the base reserve is not very relevant: although there can be regional shortages, the raw materials, limestone and sand, are geologically abundant and widespread. However, there may be environmental constraints: cement production is an important source of $\mathrm{CO}_{2}$ [49].

The conclusion that can be drawn is that if wind energy is to contribute $15 \%$ to the global primary energy use in 2050 , this would mean that a substantial amount of the base reserve of copper and iron ore needs to be invested in this sector. The worldwide production of copper, iron ore and cement would have to increase dramatically. If wind turbines are to be scaled up to the level of TWhs it does not seem likely that neodymium containing direct-drive permanent-magnet generators will play a significant role because of resource constraints related to neodymium.

\subsection{Resource constraints related to hydrogen production}

Electrolyzers based on the alkaline process have been in commercial use for decades. PEM electrolysis cells and solid oxide based electrolyzers have recently been commercially introduced. In this analysis we will therefore focus on alkaline electrolysis. The electrolyte is an alkaline solution, usually potassium or sodium hydroxide, and the electrodes are made of different coated metals. The anode is often made of nickel and copper and coated with 
oxides of metals and the cathode is made of platinum coated nickel. A theoretical maximum efficiency of $83 \%$ is given by [12]. In practice the efficiency based on $\mathrm{LHV}^{10}$ is between $50 \%$ and $75 \%$ $[31,50,51]$. Here we assume a future efficiency for the production of hydrogen from water of $75 \%$. This means that if hydrogen is used as the energy carrier in transmission, the energy collection and the connected material flows and land use will have to be $25 \%$ higher than calculated above.

In electrolysis, hydrogen is produced from fresh water. This is problematic in many places that would be ideal for PV solar power plants. In desert-like areas that are close to oceans, like the Western part of the Sahara, one could overcome this problem by combining PV plants with desalination installations. Although desalination has become much more efficient over recent years it still requires a significant energy input which would decrease the overall efficiency of hydrogen production.

Current electrolyzers are made from stainless steel, plastics and the materials needed for membranes and electrodes and the electrolyte. There is little quantitative information on the material use in the membranes and electrodes in the public domain. The electrolyte is normally potassium hydroxide or sodium hydroxide. Both of them are bulk chemicals and the use in this application would still be small compared the total annual use. The membranes are made of organic polymers, such as nafion and polybenzimidazole, and are not related to material constraints either. The electrodes are made of metals: the anode is usually a combination of nickel and copper coated with a layer of metal oxides. The anode is made of nickel coated with a layer of platinum [52]. Although we do not have much specific data on the quantity of the metals in electrolyzers we assume here that they will be in the same range as that of fuel cells. This would imply potential resource constraints with regard to Platinum (see further in this text, under "Resource constraints related to hydrogen use: Fuel Cells"). Technological innovations have a potential to solve these material issues. Recently a study was published on a promising new technique that uses a solution of much more abundant cobalt and phosphate as the main active components ${ }^{11}$ [53].

It can be concluded that material constraints of hydrogen production via electrolysis using alkalines can be expected related to platinum. PEM electrolyzers also use platinum as a catalysts and these would run into similar constraints (see Section 4.4). For solid oxide this is presently unclear, as they are not developed fully yet, but resource constraints are not necessarily absent.

\subsection{Resource constraints related to transmission}

In May 2008 the longest HVDC cable became operational and connects the electricity grids of Norway and the Netherlands. Specifications of this cable are given in Table 7. The capacity of the cable is about $600 \mathrm{MW}$ and it has a copper conductor of $760 \mathrm{~mm}^{2}$. Total transmission losses are estimated at $4 \%$ with full load [54,55]. In a scenario where solar energy is collected in remote desert areas power cables would be needed that are about a factor 10 longer than the longest operational cables today. The main materials used in these cables are copper, steel, lead and polyethylene. In Table 8 the material needs for transmission of $65 \%$ of the primary energy in 2050 through HVDV cables is calculated. The copper use in the

\footnotetext{
${ }^{10}$ The LHV assumes that the latent heat of vaporization of the water that is produced during the electrolysis is not recovered. For hydrogen the Higher Heating Value is about $18 \%$ higher than the lower heating value.

${ }^{11}$ The authors use a solution with cobalt and phosphate ions in aqueous solution at neutral $\mathrm{pH}$. In the experiments a newly formed catalyst is deposited on the electrode consisting of both cobalt and phosphate. This catalyst is highly active and will regenerate spontaneously. In the experiment an indium tin oxide (ITO) catalyst was used which by including indium has its own resource scarcity issues. However, this material was itself did not seem to be taking part the electrolysis mechanism.
}

Table 7

Details of the HVDC power cable between Norway and the Netherlands.

\begin{tabular}{ll}
\hline Conductor size & $2 \times 760 \mathrm{~mm}^{2}$ (bipolar) \\
Conductor material & Copper \\
Weight & $85 \mathrm{~kg} / \mathrm{m}$ (bipolar) \\
Outer diameter & $120 \mathrm{~mm}$ \\
Rated power & $600 \mathrm{MW}$ \\
Rated voltage & $450 \mathrm{kV}$ \\
Length & $580 \mathrm{~km}$ \\
Maximum water depth & $410 \mathrm{~m}$ \\
\hline
\end{tabular}

Sources: $[54,55]$

$600 \mathrm{MW}$ NorNed cable is about $7.5 \mathrm{~kg} / \mathrm{m}$. With increased conductor size the maximum power through this types of cables today can be several $1000 \mathrm{MW}$ [56]. If it is assumed that the conductor size would have to double when doubling the power throughput. In a $1200 \mathrm{MW}$ cable the copper use would also be doubled to $14 \mathrm{~kg} / \mathrm{m}$, in a bipolar cable this would again be doubled to $28 \mathrm{~kg} / \mathrm{m}$. If $65 \%$ of the primary energy use in 2050 would be transmitted over an average distance of $1500 \mathrm{~km}, 22$ thousand $1200 \mathrm{MW}$ (bipolar) cables would be needed. In order to produce these cables 900 million ton copper would be needed. This is equivalent to about $90 \%$ of current reserve base and twice the cumulative production between 1900 and 2001 [58], 24\% of the total copper resource and almost 70 times the current annual world production. The long-term availability of copper has been discussed in literature [59,60]. Although copper is not a rare element, still resource constraints are in sight if electricity transmission has to take place in these amounts over these large distances.

If $65 \%$ of the primary energy use in 2050 would be delivered by hydrogen through stainless steel pipelines (current technology) this would require substantial amounts of nickel and chromium. The exact specifications of pipelines may vary substantially. An estimate is given in Table 9. The starting point of the calculations was that $600 \mathrm{MW}_{\mathrm{H} 2}$ stainless steel (API 303/304/316) pipelines would be used. The number of pipelines would then be identical to the number of HVDC cables in the case of electricity transmission. Based on typical wall thickness and diameter from [29] and typical chromium and nickel content in stainless steel this result a demand for $\mathrm{Ni}$ of about 45 times the current annual mine production and for $\mathrm{Cr}$ of about 5500 times the current annual mine production. The amount of nickel needed would be equal to current reserves. The USGS does not give global reserves for chromium but the amount is about a thousand times higher than the total reserves of countries that are included in their data.

From the analysis above it is clear that, using current technologies, the use of copper in HVDC lines would be prohibit the use of HVDC transmission in our extreme scenario. The use of the much more abundant aluminum conductors might solve this issue but it would also decrease the overall efficiency of the transmission. Also the use of current technology stainless steel for the transport of hydrogen cannot be scaled up to the level that we would need in our scenario due to material constraints of chromium and nickel. Other steels or coated steels might be the best alternative here or possibly steel could be avoided completely by the use of new composite materials.

\subsection{Resource constraints related to end-use: fuel cells and electric} motors

\subsubsection{Fuel cells in cars}

In 2001 there were 555 million cars in the world [62]. In the Markets First Scenario, GDP per capita will grow by a factor of 3.7 from 2001 to 2050. It is assumed that the number of cars will grow with the same factor. This would mean that there will be roughly 2 billion cars on the road by 2050 . We assume that all these cars will have a PEM fuel cell on board. Rade and Andersson [63] use in 
Table 8

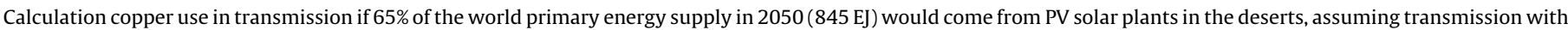
HVDC power cables.

\begin{tabular}{|c|c|c|c|}
\hline & Unit & Amount & Source \\
\hline \multicolumn{4}{|l|}{ Data on HVDC cables } \\
\hline Power through existing cable & $\mathrm{W}$ & $6.00 \times 10^{8}$ & {$[54,55]$} \\
\hline Conductor cross section for $600 \mathrm{MW}$ & $\mathrm{mm}^{2}$ & 760 & [55] \\
\hline Maximum power per cable & W & $1.20 \times 10^{9}$ & [56] \\
\hline Conductor cross section for $1200 \mathrm{MW}$ & $\mathrm{mm}^{2}$ & 1520 & $\begin{array}{l}\text { Assumption: double power, } \\
\text { double conductor cross section }\end{array}$ \\
\hline Volume copper per m cable & $\mathrm{cm}^{3}$ & 3200 & Calculated \\
\hline Density conductor (copper) & $\mathrm{g} / \mathrm{cm}^{3}$ & 8.9 & [57] \\
\hline Mass copper & $\mathrm{g} / \mathrm{m}$ cable & 13,500 & Calculated \\
\hline \multicolumn{4}{|l|}{ Calculation cables needed } \\
\hline Total energy use 2050 & $\mathrm{~J} / \mathrm{a}$ & $1.3 \times 10^{21}$ & assumption in this study \\
\hline Total energy use 2050 & $\mathrm{~W}$ & $4.1 \times 10^{13}$ & Calculated \\
\hline $65 \%$ from deserts & W & $2.6 \times 10^{13}$ & Calculated \\
\hline Number of cables needed & - & 21,951 & Calculated \\
\hline Average distance to end-users & $\mathrm{km}$ & 1500 & assumption in this study \\
\hline km cable needed & $\mathrm{km}$ & $3.3 \times 10^{7}$ & Calculated \\
\hline \multicolumn{4}{|l|}{ Calculation total copper use for transmission } \\
\hline Total copper use monopolar & $\mathrm{kg}$ & $4.5 \times 10^{11}$ & Calculated \\
\hline Total copper use if bipolar & $\mathrm{kg}$ & $8.9 \times 10^{11}$ & Calculated \\
\hline \multicolumn{4}{|l|}{ Comparison to copper production $\&$ base reserve } \\
\hline Base reserve $(\mathrm{Cu})$ & $\mathrm{kg}$ & $1 \times 10^{12}$ & [47] \\
\hline Resources (land and ocean) & $\mathrm{kg}$ & $3.7 \times 10^{12}$ & [47] \\
\hline Mine production & $\mathrm{kg} / \mathrm{a}$ & $1.6 \times 10^{10}$ & [47] \\
\hline Cumulative world production 1900-2001 & $\mathrm{kg}$ & $4.2 \times 10^{11}$ & {$[58]$} \\
\hline Multiplier copper use transmission vs base reserve & - & 0.89 & Calculated \\
\hline Multiplier copper use transmission vs resources & - & 0.24 & Calculated \\
\hline Multiplier copper use transmission vs mine production & - & 57 & Calculated \\
\hline $\begin{array}{l}\text { Multiplier copper use transmission vs cumulative mine } \\
\text { production (1900-2001) }\end{array}$ & - & 2.1 & Calculated \\
\hline
\end{tabular}

their baseline scenario, based on current technologies, that in PEM fuel cells on average $0.39 \mathrm{~g}$ of Pt is needed per $\mathrm{kW}$. With 2 billion cars on the road in 2050 this would mean that 39,000 ton of Pt would be needed. Since the platinum catalyst is an expensive part of the fuel cell, R\&D will be aimed at reducing the amount of platinum needed in fuel-cell vehicles. The UK Department for Transport reports an ultimate goal of about $3 \mathrm{~g}$ per car which would mean a demand for Platinum of about 6000 ton in 2050 (DfT, 2003). Currently platinum group metals (PGM) are used as catalysts. The USGS estimates the reserve base at 80,000 ton and world resources at over 100,000 ton [47]. World production in 2008 was 200 ton Platinum and 206 ton Palladium [47]. The cumulative production of PGM from 1900 to 2000 is 9120 ton [65]. In Table 10 the amount of platinum in fuel cells is calculated. If the goals for the reduction of Pt in fuels cells are met less than $10 \%$ of the base reserve is needed. However, using current technologies the amount of Pt in cars in 2050 would exceed the world resources. In any case the production rates would have to grow dramatically to fulfill the demand.

The problem of Pt use might be solved in future by using alternative catalysts which do not contain rare metals. The two main alternatives are the use of base metals and the use of enzymes. However, for hydrogen fueled fuel cells there are no known (combinations of) base metals that can be practical substitutes for PGM metals yet. The enzyme route is more promising although a practical enzyme based biofuel cell is [67] also still in the early stages of fundamental research. Currently technologies are being developed to adsorb enzymes like hydrogenase on electrodes which brings the biofuel cell a bit closer to practical application [68].

\subsubsection{Stationary fuel cells for power generation}

If hydrogen is used for the transmission of energy a substantial part of this should be transformed again to electricity. This can be done by combustion of hydrogen which in power plants that are comparable to current natural gas fired power plants. This option would thus not be confronted with additional material constraints. However, it would be more efficient to use fuel cells in stead. This would mean that stationary fuel cells would be used to convert hydrogen into electricity. Large stationary fuel cells are small compared to current power plants. This means that power generation will be distributed in which case the power grid would only be used for local distribution. There are different types of stationary fuel cells: phosphoric-acid fuel cells (PAFC), moltencarbonate fuel cells (MCFC) and solid oxide fuel cell (SOFC). Although we did not quantify this it seems likely that both PAFCs and SOFCs would be confronted with resource constraints: in PAFCs platinum is used and in SOFCs lanthanum is used. In MCFCs less scarce materials like $\mathrm{Ni}, \mathrm{Cr}$ and $\mathrm{Al}$ can be used as electrode materials. The material constraints with in stationary fuel cells will be less severe than for the use of fuel cells in cars.

\subsubsection{Electric motors in cars}

Fuel cells in cars are used to produce electricity which is used to power the electromotors that make the wheels turn. The use of neodymium in electromotors make these motors smaller, lighter and more efficient. Reliable sources on the amount of Nd in cars have not been found. However, figures of 1-2 kg of neodymium for a Toyota Prius can be found in the media (e.g. [66]). For the 2 billion cars on the road in 2050, 2-4 million ton of neodymium would be needed, about 200 times the current annual production. For full electric cars using permanent-magnet motors these number would be higher. However, like in wind turbines alternatives are possible. The Tesla roadster for example, uses an induction motor without permanent magnets.

Resource constraints will prohibit the scale up of the use of fuel cells in cars due to constraints in the availability of platinum. An extreme reduction of the amount of platinum per fuel cell might 
Table 9


assuming transmission with hydrogen pipelines.

\begin{tabular}{|c|c|c|c|}
\hline & Unit & Amount & Source \\
\hline \multicolumn{4}{|l|}{ Data on hydrogen pipelines } \\
\hline Power through pipeline $\left(600 \mathrm{MW}_{-} \mathrm{H}_{2}\right)$ & W & $6.0 \times 10^{8}$ & [29] \\
\hline Pipe diameter & $\mathrm{cm}$ & 25 & [29] \\
\hline Wall thickness & $\mathrm{cm}$ & 1.0 & Average API 10 pipe \\
\hline Volume steel per m pipe & $\mathrm{cm}^{3}$ & 2500 & Calculated \\
\hline Density stainless steel & $\mathrm{g} / \mathrm{cm}^{3}$ & 8 & [61] \\
\hline Mass steel & $\mathrm{kg} / \mathrm{m}$ pipe & 20 & Calculated \\
\hline Fraction Ni in stainless steel & - & 0.11 & Average $304,306,316$ \\
\hline Fraction $\mathrm{Cr}$ in stainless steel & - & 0.18 & Average $304,306,316$ \\
\hline Fraction Fe in stainless steel & - & 0.71 & Remaining fraction \\
\hline Mass $\mathrm{Ni}$ & $\mathrm{kg} / \mathrm{km}$ pipe & 2200 & Calculated \\
\hline Mass $\mathrm{Cr}$ & $\mathrm{kg} / \mathrm{km}$ pipe & 3600 & Calculated \\
\hline Mass Fe & $\mathrm{kg} / \mathrm{km}$ pipe & 14,200 & Calculated \\
\hline \multicolumn{4}{|l|}{ Calculation pipelines needed } \\
\hline Total energy use 2050 & $\mathrm{~J} / \mathrm{a}$ & $1.3 \times 10^{21}$ & Assumption in this study \\
\hline Total energy use 2050 & W & $4.1 \times 10^{13}$ & Calculated \\
\hline $65 \%$ in centralised scenario from deserts & W & $2.6 \times 10^{13}$ & Calculated \\
\hline Number of pipelines needed & - & 22,000 & Calculated \\
\hline Average distance to end-users & $\mathrm{km}$ & 1500 & Assumption in this study \\
\hline km pipeline needed & $\mathrm{km}$ & $3.3 \times 10^{7}$ & Calculated \\
\hline \multicolumn{4}{|l|}{ Calculation total $\mathrm{Ni}$ and $\mathrm{Cr}$ use for transmission } \\
\hline Total Ni use & $\mathrm{kg}$ & $7.2 \times 10^{10}$ & Calculated \\
\hline Total $\mathrm{Cr}$ use & $\mathrm{kg}$ & $1.2 \times 10^{11}$ & Calculated \\
\hline Total Fe use & $\mathrm{kg}$ & $4.7 \times 10^{11}$ & Calculated \\
\hline \multicolumn{4}{|l|}{ Comparison to production and base reserves } \\
\hline Base reserve $(\mathrm{Ni})$ & $\mathrm{kg}$ & $1.50 \times 10^{11}$ & [47] \\
\hline Mine production (Ni) & $\mathrm{kg} / \mathrm{a}$ & $1.61 \times 10^{9}$ & [47] \\
\hline Base reserve $(\mathrm{Cr})$ & $\mathrm{kg}$ & $3.74 \times 10^{11}$ & [47] Total based on main producers \\
\hline Mine production $(\mathrm{Cr})$ & $\mathrm{kg} / \mathrm{a}$ & $2.15 \times 10^{7}$ & {$[47]$} \\
\hline Base reserve $(\mathrm{Fe})$ & $\mathrm{kg}$ & $1.6 \times 10^{14}$ & [47] \\
\hline Mine production (Fe) & $\mathrm{kg} / \mathrm{a}$ & $1.2 \times 10^{12}$ & [47] \\
\hline Multiplier Ni use pipelines/base reserve & - & 0.48 & Calculated \\
\hline Multiplier Ni use pipelines/mine production & - & 45 & Calculated \\
\hline Multiplier $\mathrm{Cr}$ use pipelines/base reserve & - & 0.32 & Calculated \\
\hline Multiplier $\mathrm{Cr}$ use pipelines/mine production & - & 5500 & Calculated \\
\hline Multiplier Fe use pipelines/base reserve & - & 0.0029 & Calculated \\
\hline Multiplier Fe use pipelines/mine production & - & 0.39 & Calculated \\
\hline
\end{tabular}

Table 10

Calculation of Pt and Nd use in fuel-cell cars in 2050.

\begin{tabular}{|c|c|c|c|}
\hline & & Unit & Source \\
\hline Number of cars on the road in 2050 & $2.0 \times 10^{9}$ & - & Assumption based on GDP growth \\
\hline Pt per car (high) & 60 & $\mathrm{~g} / \mathrm{car}$ & [64] \\
\hline Pt per car (low) & 20 & $\mathrm{~g} / \mathrm{car}$ & [63] \\
\hline Pt per car (minimum) & 3 & $\mathrm{~g} / \mathrm{car}$ & [64] \\
\hline Pt for all cars in 2050 (high) & 120,000 & ton & Calculated \\
\hline Pt for all cars in 2050 (low) & 47,000 & ton & Calculated \\
\hline Pt for all cars 2050 (minimum) & 6000 & ton & Calculated \\
\hline World production Pt 2007 & 220 & ton & {$[36]$} \\
\hline Multiplier (high) & 530 & - & Calculated \\
\hline Multiplier (low) & 220 & - & Calculated \\
\hline Multiplier (minimum) & 28 & - & Calculated \\
\hline Nd per car (low) & 1 & $\mathrm{~kg} / \mathrm{car}$ & [66] Uncertain! \\
\hline Nd per car (high) & 2 & $\mathrm{~kg} / \mathrm{car}$ & [66] Uncertain! \\
\hline Nd for all cars in 2050 (low) & 2000 & kton & Calculated \\
\hline Nd for all cars in 2050 (high) & 4000 & kton & Calculated \\
\hline World production Nd 2008 & 20 & kton & [66] \\
\hline Multiplier (high) & 100 & - & Calculated \\
\hline Multiplier (low) & 200 & - & Calculated \\
\hline
\end{tabular}

solve this issue. The use of other, less scarce, electrode materials might also be a way out. Stationary fuel cells needed to produce electricity in a scenario where hydrogen will be used for the transmission will run into similar, though less severe because the installed capacity can be much lower because they are used almost 24/7. Neodymium magnets are an issue in electric vehicles if permanent-magnet motors will be used. However, alternatives like the induction motor that do not contain permanent motors are available.

\section{Conclusions and discussion}

The limiting factor for a renewable based hydrogen energy system does not lie in the amount of renewable energy that is 
available. There is plenty of wind and especially solar energy to provide for an exponentially growing world economy. However, since wind and solar energy are diffusive energy sources the infrastructure needed to harvest substantial amounts is huge. In order to limit the amount of infrastructure needed for harvesting it is important to choose locations where the circumstances for harvesting are optimal. Especially for solar energy these locations are quite often far from the locations where this energy is used. Therefore an extensive transmission network is needed in addition, to get the energy in the right place.

In this study we have shown that the choice of technology has a strong influence on the material resources that are needed in such a system. In three crucial parts of the system we describe the use of relatively scarce materials as show stoppers for specific technologies: rare elements in current thin-film solar cells, neodymium in direct-drive permanent-magnet wind turbines and electro motors, and platinum in electrolysis and fuel cells. Resource constraints prevent these technologies from upscaling to a level that would be needed for a substantial transition to a renewable based hydrogen economy. For a worldwide conversion to renewable energy, therefore, different technologies must be chosen and/or developed that do not rely on these scarce materials. Many of these technologies are available be it sometimes at the cost of efficiency and/or economics.

Furthermore, the amount of steel that would be needed for both wind turbines and hydrogen pipelines is very high. For wind turbines, this would be 6 times the current annual production of iron for hydrogen pipelines $40 \%$. However, if current technology stainless steel is used for the pipelines about 45 times the annual production of nickel would be needed and 5500 times the annual production of chromium. If electricity is chosen as a carrier, the amount of copper that would be needed in the system is equivalent to 70 times the current annual world production. For the wind turbines an additional 4 times the current annual world copper production would be needed. Although resource constraints for iron ore are not in sight, it would imply a major increase in worldwide energy and, in the current system, fossil fuel use. The same is true for copper. While scarcity is not an immediate issue, the energy required to mine increasingly lower ore grades could become very large, thus creating a negative spiral.

This paper is a first step in the analysis of changes in material needs as a result of energy transitions. There are some important issues that we have not addressed yet. This study focuses on the direct material needs only. The life-cycle perspective is not applied. If it would be, the material needs would probably be much higher. Moreover, the energy system that we use as a starting point is an extreme case that is not predicted in any of the major energy scenarios. However, it was not our intention to sketch a realistic energy scenario for 2050 but to explore the material needs of a complete transition. A partial transition would of course decrease the material needs, as would a limitation of primary energy needs. However, we also made some major simplifications that underestimate material needs. For example the intermittent nature of solar and wind as energy sources will make some sort of buffering an essential part of the energy system. In the large-scale energy system perspective that we have used here, this could be done for example by high capacity east-west power lines that would compensate for the day-night rhythm of PV. These cables would have to be much longer than the ones we have assumed here, which would decrease the efficiency of the system as a whole. If hydrogen would be the energy carrier of choice for transmission, intermittency might be buffered by allowing changes in pressures in the pipelines.

Further in-depth analysis is needed to assess the material needs of a transition to a renewable based energy systems. Including the life-cycle perspective could be a means to detect mechanisms that have a potential to make the system spiraling out of control. The increasing use of energy to produce the materials required to generate energy could be such a mechanism. Another large research area is introducing the dynamics of actual transformations. This will lead to more detailed and realistic estimations of material needs through time in different scenarios.

Another issue is the environmental aspects of these energy systems. The systems are designed to reduce greenhouse gas emissions. A first relevant question would be, if this is indeed the case. If material requirements explode, so might the use of fossil fuels in build-up phase of the system. But even if a substantial reduction of greenhouse gas emissions would be reached, still there may be side-effects in other areas of environmental impacts, such as land and water use, emissions of toxic substances, etc. These side-effects need to be investigated as well, in order to be able to have a balanced assessment of alternative energy systems.

Finally, a sustainability approach is not limited to scarcity and environmental impacts, but also includes economic and social aspects. These have not been addressed in this paper, but should be addressed in a more comprehensive sustainability assessment.

\section{References}

[1] European Commission. Hydrogen Energy and Fuel Cells; A vision of our future. EUR 20719 EN. European Commission; 2003.

[2] The White House. A new generation of American innovation, April 2004. The White House; 2004.

[3] U.S. Department of Energy. Hydrogen posture plan. An integrated research, development and demonstration plan. U.S. Department of Energy; 2004.

[4] Okano, Kazukiyo. Hydrogen and fuel cell activities in Japan. PATH hydrogen workshop, Mexico, February 14; 2003.

[5] Tromp TK, Shia R-L, Allen M, Eiler JM, Yung YL. Potential environmental impact of a hydrogen economy on the stratosphere. Science 2003;300(June (3)):2003.

[6] Schultz MG, Diehl T, Brasseur GP, Zittel W. Air pollution and climate-forcing impacts of a global hydrogen economy. Science 2003;302(October):624-7.

[7] Prather MJ. An environmental experiment with H2? Science 2003;302:581-2.

[8] Odell PR. Why carbon fuels will dominate the 21 st century's global energy economy. Brentwood Essex, UK: Multi-Science Publishing Co. Ltd.; 2004.

[9] UNEP. Global environment outlook 3. London: Earthscan Publications Ltd. 2002.

[10] IEA. World Energy Outlook 2007. China and India Insights. OECD/IEA 2007, Paris, France; 2007.

[11] Shell. Shell energy scenarios to 2050. Shell International BV (http://wwwstatic.shell.com/static/aboutshell/downloads/our_strategy/shell_global_scenarios/SES\%20booklet\%2025\%20of\%20July\%202008.pdf); 2008.

[12] Sørensen B. Renewable energy, its physics, engineering, use, environmental impacts economy and planning aspects. London: Academic Press; 2000

[13] Leijendeckers PHH, Jansen JLA, Keukeleere DCEM. Energie zakboek (Energy Handbook). Doetinchem: Reed Business; 2008.

[14] Williams RH. Nuclear and alternative energy supply options for an environmentally constrained world; a long-term perspective. In: Nuclear Control Institutes 20th Anniversary Conference Nuclear Power and the Spread of Nuclear Weapons: Can We Have One Without the Other?; 2001.

[15] Hoogwijk, M.M. On the global and regional potential of renewable energy sources. Thesis. Universiteit Utrecht; 2004.

[16] Hoogwijk M, Faaij A, van den Broek R, Berndes G, Gielen D, Turkenburg W. Exploration of the ranges of the global potential of biomass for energy. Biomass \& Bioenergy 2003;25:119-33.

[17] Doornbosch R, Steenblik R. Biofuels: is the cure worse than the disease? Round Table on Sustainable Development, OECD, SG/SD/RT(2007)3. OECD Paris; 2007.

[18] Knies G, Bennouna A. Potential of Moroccan renewable energies for the defence against climate change. FIER; 2002

[19] Czisch G. Least-Cost European/Transeuropean Electricity Supply Entirely with Renewable Energies, ISET 2004, www.iset.uni-kassel.de; 2004.

[20] Seboldt W. Space- and Earth-based solar power for the growing energy needs of future generations. Acta Astronautica 2004;55:389-99.

[21] Melis A, Happe T. Hydrogen production. Green algae as a source of energy. Plant Physiology 2001;127:740-8.

[22] Oxera. The impact of average zonal transmission losses applied throughout Great Britain. Department of Trade and Industry; 2003.

[23] IEA. Energy technology perspectives 2008, Scenarios and strategies to 2050 OECD/IEA, Paris, France; 2008.

[24] Weindorf W, Bünger U, Schindler J. Comments on the paper by Baldur Eliasson and Ulf Bossel "The Future of the Hydrogen Economy: Bright or Bleak". L-BSystemtechnik GmbH, Ottobrun, Germany; 2003. 
[25] Sørensen B. Renewable energy, conversion, transmission and storage. London: Academic Press; 2007.

[26] Basslink. Response by Basslink Pty Ltd to Draft Report of the Basslink Joint Advisory Panel. Submission 2 of 3, Proposed Metallic Return. Basslink, Melbourne, Australia; 2002.

[27] Zittel W, Altmann M. Molecular hydrogen and water vapour emissions in a global hydrogen energy economy 1996. In: Proceedings of the 11th World Hydrogen Energy Conference; 1996.

[28] Bossel U, Elliasson B, Taylor G. The future of the hydrogen economy Bright or Bleak. Energy and the Hydrogen Economy. Final Report (to be published http:// www.methanol.org/pdf/HydrogenEconomyFinalReport.pdf); 2003.

[29] Ball M, Weindorf W, Bünger U. Hydrogen distribution. In: Ball M, Wietschel M editors. The hydrogen economy, opportunities and challenges. New York: Cambridge University Press; 2009.

[30] Blazek CF, Biederman RT, Foh SE, Jasionowski W. Underground storage and transmission of hydrogen. In: Proceedings of the Third Annual US Hydrogen Meeting; 1992.

[31] Ogden JM. Prospects for building a hydrogen energy infrastructure. Annual Reviews of Energy and the Environment 1999;24:227-79.

[32] Wietschel M, Ball M, Seydel P. Hydrogen today. In: Ball M, Wietschel M, editors. The hydrogen economy, opportunities and challenges. New York: Cambridge University Press; 2009.

[33] Faass. Flugzeuge mit wasserstofantrieb (Aircraft with hydrogen propulsion). Airbus Deutschland (http://www.fzt.haw-hamburg.de/pers/Scholz/dglr/hh/ text_2001_12_06_Cryoplane.pdf); 2001.

[34] IEA. Potential for Building Integrated Photovoltaics. Report IEA - PVPS T74:2002. IEA Paris, France; 2002.

[35] IMAGE team. The IMAGE 2.2 implementation of the SRES scenarios: A comprehensive analysis of emissions, climate impacts in the 21 st century. RIVM CD-ROM publication 481508018, National Institute for Public Health and the Environment, Bilthoven. The Netherlands; July 2001.

[36] USGS Minerals Yearbook 2007; 2009.

[37] Wadia C, Alivisatos AP, Kammen DM. Materials availability expands the opportunity for large-scale photovoltaics deployment. Environ Sci Technol 2009;43(6)

[38] Fthenakis V. Sustainability of photovoltaics: the case for thin-film solar cells. Renewable and Sustainable Energy Reviews 2009;13:2746.

[39] Green MA, Emery K, King DL, Hishikawa Y, Warta W. Solar Cell Efficiency Tables (Version 28) 2006 Progress in photovoltaics: Research and Applications vol. 14 p. 455-61. doi:10.1002/pip.720; 2006.

[40] Andersson BA, Azar C, Holmberg J, Karlsson S. Material constraints for thin film solar cells. Energy - The International Journal 1998;23:407.

[41] Andersson BA. Material Constraints on Technology Evolution: The case of scarce metals and emerging energy technologies. PhD Thesis. Chalmers University of Technology Goteborg University, Goteborg, Sweden.

[42] Andersson BA, Jacobsson S. Monitoring and assessing technology choice: the case of solar cells. Energy Policy 2000;28:1037-49.

[43] van Kuik GAM. Are wind turbines growing too fast?In: 2001 European Wind Energy Conference and Exhibition; 2001.p. 69-72;

In: Slootweg J.G. 2003. Wind Power, Modelling and Impact on Power System Dynamics thesis, Delft University of Technology, Netherlands; 2001.

[44] Ecoinvent v2.0 LCA database, Swiss Centre for Life Cycle Inventories, Duebendorf, $\mathrm{CH}$.

[45] Polinder H, van der Pijl FFA, de Vilder G, Tawner PJ. Comparison of direct-drive and geared generator concepts for wind turbines. IEEE Transactions on Energy Conversion 2006;21(3).

[46] Hatch GP. Going green: the growing role of permanent magnets in renewable energy production and environmental protection. In: Magnetics 2008 Conference held in Denver (Co); 2008.

[47] USGS. Mineral Commodity Summaries 2009; 2009.
[49] Kleijn R, van der Voet E, Udo de Haes HA. The need for combining IEA and IE tools: the potential effects of a global ban on PVC on climate change. Ecological Economics 2008;65:266-81.

[50] IEA. Prospects for hydrogen and fuel cells. OECD/IEA 2005, Paris, France; 2005.

[51] Turner. Sustainable hydrogen production. Science 305, 972-973. U.S. Department of Energy (2004) Hydrogen posture plan. An integrated research, development and demonstration plan. U.S. Department of Energy; 2004.

[52] Koroneos C, Dompros A, Roumbas G, Moussiopoulos N. Life cycle assessment of hydrogen fuel production processes. International Journal of Hydrogen Energy 2004;29:1443-50.

[53] Kanan MW, Nocera DG. In situ formation of an oxygen-evolving catalyst in neutral water containing phosphate and Co2+. Science 2008;321:1072-5.

[54] Tennet. NorNed, Europe's link to the future. Tennet, Arnhem, Netherlands; 2007.

[55] Statnett. NorNed cable, HVDC project. Statnett, Oslo Norway; 2002.

[56] ABB website, http://www.abb.com/cawp/seitp202/A4CA486DE1BF9C18C12 57368002B05E1.aspx.

[57] CRC, Handbook of Physics and Chemistry.

[58] Porter KE, Edelstein DIL. Copper statistics. USGS; 2003.

[59] Gordon RB, Bertram M, Graedel TE. Metal stocks and sustainability. Proceedings of the National Academy of Sciences of the United States of America 2006;103(5):1209-14.

[60] Tilton JE, Lagos G. Assessing the long-run availability of copper. Resources Policy 2007;31(1-2).

[61] The Physics Factbook (http://hypertextbook.com/facts/).

[62] Worldwatch. Worldwatch Database: CD-Rom, Vital Signes; 2002.

[63] Rade I, Andersson BA. Platinum group metal resource constraints for fuel-cell vehicles. PRT Report 2001:01. Department of Physical Resource Theory, Chalmers University of Technology and Göteborg University. Sweden; 2001.

[64] DfT. Platinum and hydrogen for fuel cell vehicles. UK Department for Transport; 2003.

[65] Kelly TD, Hilliard HE. Platinum-group metals statistics. USGS; 2003.

[66] Reuters. As hybrid cars gobble rare metals, shortage looms. http://www. reuters.com/article/idUSTRE57U02B20090831. Reuters, Los Angeles; 2009.

[67] Armstrong FA, Belsey NA, Cracknell JA, Goldet G, Parkin A, Reisner E, Vincent KA, Wait AF. Dynamic Electrochemical Investigations of Hydrogen Oxidation and Production by Enzymes and Implications for Future Technology. Chemical Society Reviews 2009;38:36-51.

[68] Lamle SE, Vincent KA, Halliwell LM, Albracht SPJ, Armstrong FA. Hydrogenase on an electrode: a remarkable heterogeneous catalyst. Dalton Transactions 2003;4152-7. Issue 21.

[69] Bungay HR. Confessions of a bioenergy advocate. Trends in Biotechnology 2002;22(2). February 2004.

[70] Kaltschmitt, M.; Reinhardt, G.A. Nachwachsende Energieträger. Grundlagen, Verfahren, Ökologische Bilanzierung. (In German). Braunschweig/Wiesbaden, Germany: Friedr. Vieweg \& Sohn Verlagsgesellschaft. ISBN 3-528-06778-0. p. 548; 1997.

[71] European Commission. Biomass, green energy for Europe. EU DirectorateGeneral for Research, Directorate J-Energy, Unit 3-New and Renewable Energy Sources. EUR 21350; 2005.

[72] Fujishima A. Honda K. Electrochemical photolysis of water at a semiconductor electrode. Nature 1972;238:37.

[73] Khaselev O, Turner JA. A monolithic photovoltaic-photoelectrochemical device for hydrogen production via water splitting. Science 1998;280:425-7.

[74] Grätzel M. Photoelectrochemical cells. Nature 2001;414:338-44.

[75] Wright SD, Rogers AL, Manwell JF, Ellis A. Transmission options for offshore wind farms in the United States. Renewable Energy Research Lab. Amherst, USA: University of Massachusetts, Department of Mechanical and Industrial Engineering; 2002.

[76] Meijer A, Huijbregts MAJ, Schermer JJ, Reijnders L. Life-cycle assessment of photovoltaic modules: comparison of $\mathrm{mc}-\mathrm{Si}$, InGaP and InGaP/mc-Si solar modules. Progress in Photovoltaics Research and Applications 2003;11:275-87. 